\title{
Pathophysiology, Diagnosis and Treatment of Pulmonary Embolism Focusing on Thrombolysis - New approaches
}

\author{
Diana Mühl, Gábor Woth, Tamás Kiss, \\ Subhamay Ghosh and Jose E. Tanus-Santos \\ ${ }^{1}$ Department of Anaesthesia and Intensive Care, University of Pécs, Pécs \\ ${ }^{2}$ Department of Pharmacology, Faculty of Medicine of Ribeirao Preto \\ University of Sao Paulo, Ribeirao Preto, SP \\ ${ }^{1}$ Hungary \\ ${ }^{2}$ Brazil
}

\section{Introduction}

\subsection{Incidence and mortality of pulmonary embolism}

Pulmonary embolism (PE) is not a disease by itself but may have a venous thrombotic source and is therefore more precise if classified as venous thromboembolism (VTE). According to the international registry, the frequency of VTE is 150-200 new cases diagnosed per 100,000 inhabitants per year. Out of this, one third is diagnosed as primary PE (Oger, 2000; Walther et al., 2009). Following the diagnosis the average mortality is $11 \%$ in the first two months (Goldhaber et al., 1999). In the ICOPER study, the total mortality of PE in the first 3 months was $17.5 \%$. However, in the long run the recurrent embolic episodes and lack of revascularisation caused progressive pulmonary hypertension (Goldhaber et al., 1999). The mortality of untreated PE is $30 \%$ and with adequate treatment can be reduced to $2-8 \%$ (Goldhaber, 1998). The hospital mortality of haemodynamically stable PE patients is overall $10 \%$ in general, $4 \%$ in the first 24 hours (Kline et al., 2003). Mortality of PE with respiratory and cardiovascular failure on hospital admission can be up to $95 \%$. Hospital mortality is $80 \%$ in patients requiring mechanical ventilation and $77 \%$ in those who need cardiopulmonary resuscitation in the first 24 hours (Janata et al., 2002). Only 29\% of fatal PE cases (verified at hospital autopsies) were previously diagnosed clinically. Based on these facts, the primary goal in PE management is a rapid and clear diagnosis followed by the appropriate treatment (S. Büchner \& Th. Hachenberg, 2005).

\subsection{Etiology}

The source of PE in majority of cases can be due to the postoperative state, trauma injury, long term immobilization causing deep vein thrombosis (DVT), or congenital/acquired coagulation defect (Goldhaber \& Morrison, 2002; Schürmann et al., 1992; Spöhr et al., 2005; Tapson, 2008). There are congenitally predisposed and non-influenced factors in the aetiology of VTE. Most important ones are: old age, family predisposition, genetic defects - 
activated protein C resistance (Dahlbäck, 1995), 20210A mutation of factor II (Poort et al., 1996), hyperhomocysteinaemia (den Heijer et al., 1996), antithrombin III, protein C and protein S deficiency (Demers et al., 1992).

Aetiology can be divided into two groups:

a) Congenital risk factors: Lack of anti-thrombin III $(0.2 \%)$, lack of protein C $(0.8 \%)$, lack of protein S $(1.3 \%)$, Leiden point-mutation of factor V $(3.0 \%)$, mutation of prothrombin G20210 A (2.3\%) (Ageno et al., 2006).

b/ Acquired risk factors: DVT, phlebitis, immobilization, bed rest, post-traumatic and operative state, sepsis, diabetes, smoking, hypovolaemia, diuretic treatment, elevated plasma/blood viscosity, coagulation disorders (disseminated intravascular coagulation, heparin induced thrombocytopenia (HIT), drug induced coagulopathy (anticoncipient, oestrogen), obesity, sedentary lifestyle, pregnancy, postnatal state, cardiac insufficiency, heart valve disorders, artificial valves, central venous catheter, pacemaker electrode, tumour, old age, nephrosis syndrome (Goldhaber et al., 1997).

\subsection{Pathophysiology}

Based on the occlusion of the pulmonary vasculature we can differentiate between mild: $<25 \%$, intermediate: $25-50 \%$ and severe: $>50 \%$ PE types. The pathophysiology of PE runs on two parallel pathways:

- haemodynamic alterations: The oxygen demand and workload on the right atrium increases with the afterload, while cardiac index decreases (even with normal arterial blood pressure and tachycardia) leading to systemic hypotension. The right intraatrial pressure increases and the pressure gradient between the right atrium and the aorta drops, pushing the intraventricular septa into the cavity of the left ventricle (LV) (Dsign). A severe shock with global cardiac ischemia can develop.

- hypoxaemia: Ventilation/perfusion (V/Q) disequilibrium rises. Areas with hypoperfusion have an increased $\mathrm{V} / \mathrm{Q}$, while it decreases on hypoventilated (atelectasis) or normally perfused regions. Low LV cardiac output results from shuntperfusion and hypoxaemia (Nowak et al., 2007). Platelet released vasoactive substances cause vaso- and bronchospasm in the affected regions (Stratmann \& Gregory, 2003; Wood, 2002; Konstantinides, 2005). Surfactant production impairs in the early phase of pulmonary hypertension. Due to shunt-perfusion, global arterial hypoxaemia develops with a decrease of arterial oxygen saturation (Konstantinides \& Hasenfuss, 2004).

\subsubsection{Risk stratification}

Based on the haemodynamic symptoms,PE can be either massive, characterised by systolic blood pressure lower than $90 \mathrm{mmHg}$ or a systolic blood pressure decrease $>40 \mathrm{mmHg}$, or non-massive which includes submassive severity characterised by increased right ventricular pressure (Torbicki et al., 2000).

The most recent PE guideline changed the definitions of various risk groups, according: high risk and non-high risk categories.

High risk definition: Shock and/or hypotension (systolic blood pressure $<90 \mathrm{mmHg}$ or a drop in blood pressure greater than $40 \mathrm{mmHg}$ within $15 \mathrm{~min}$. excluding other causes of shock (e.g. arrhythmia, hypovolaemia, sepsis etc.).

All others can be listed under non-high risk PE. Based on right ventricular (RV) pressure overload and myocardial injury, we can differentiate a subgroup, the intermediate risk PE patients without shock. 


\begin{tabular}{|c|c|c|c|c|c|}
\hline \multicolumn{2}{|c|}{$\begin{array}{c}\text { Mortality } \\
\text { risk }\end{array}$} & \multicolumn{2}{|r|}{ Risk } & markers & \\
\hline & & $\begin{array}{c}\text { shock/hypo } \\
\text { tension }\end{array}$ & $\begin{array}{c}\text { RV } \\
\text { dysfunction }\end{array}$ & $\begin{array}{c}\text { Myocardial } \\
\text { injury }\end{array}$ & $\begin{array}{l}\text { Potential } \\
\text { treatment }\end{array}$ \\
\hline \multicolumn{2}{|c|}{ High $>15 \%$} & + & $(+)$ & $(+)$ & $\begin{array}{c}\text { Thrombolysis or } \\
\text { embolectomy }\end{array}$ \\
\hline \multirow{4}{*}{$\begin{array}{l}\text { Non } \\
\text { high }\end{array}$} & \multirow{3}{*}{$\begin{array}{l}\text { medi- } \\
\text { ate } \\
3-15 \%\end{array}$} & \multirow{3}{*}{ - } & + & + & \multirow{3}{*}{$\begin{array}{l}\text { Hospital } \\
\text { admission }\end{array}$} \\
\hline & & & + & - & \\
\hline & & & - & - & \\
\hline & $\begin{array}{l}\text { Low } \\
<1 \%\end{array}$ & - & - & - & $\begin{array}{l}\text { Early discharge or } \\
\text { home treatment }\end{array}$ \\
\hline
\end{tabular}

$(+)$ Presence of shock/hypotension it is not necessery confirm RV dysfunction

Table 1. Risk stratification according to the ESC 2008 guidelines.

The prognosis of the increased RV pressure (intermediate risk) group is worse than the normal RV pressure group (Torbicki et al., 2008).

\begin{tabular}{|l|l|}
\hline $\begin{array}{l}\text { The clinical probability of pulmonary embolism in outpatients } \\
\text { (Wells et al., 2001) }\end{array}$ & Score \\
\hline & \\
\hline Clinical signs & \\
\hline Deep vein thrombosis (DVT) & +3.0 \\
\hline Pulmonary embolism (PE) suspected from other signs or symptoms & +3.0 \\
\hline Hearth rate $>100 /$ min & +1.5 \\
\hline Operation, immobilization, bed rest in the last 4 weeks & +1.5 \\
\hline Former DVT or PE & +1.5 \\
\hline Hemoptysis & +1.0 \\
\hline Malignancy (active or confirmed in the last 6 months) & +1.0 \\
\hline & \\
\hline Probability of PE & \\
\hline Small & $<2.0$ \\
\hline Medium & $2.0-6.0$ \\
\hline High & $>6.0$ \\
\hline
\end{tabular}

Table 2. Clinical probability score

\subsection{Pulmonary embolism diagnostic strategy}

Acute PE, in the presence of shock/hypotension, RV dysfunction and myocardial injury causes high mortality risk. Rapid and clear diagnosis and appropriate therapy may help to improve survival of this critical condition. 


\subsubsection{Physical signs of PE}

In the presence of typical physical signs (dyspnoea, chest pain, syncope, tachypnea, tachycardia, cough, hemoptysis, signs of DVT, cyanosis, etc.) the diagnosis of PE is $90 \%$ reliable, although the severity of symptoms do not correlate with the actual illness. About $10 \%$ of high-risk cases are recognised by radiology imaging and considered to be non-high risk according to physical symptoms.

Physical signs and symptoms: severe stabbing chest pain (52\%), tachycardia (26\%), cough $(20 \%)$, cyanosis $(15 \%)$ or paleness, increased perspiration, fever $(38.5 \%)$, dyspnoea (with acute onset $80 \%)$, tachpnea (70\%), hemoptysis (11\%), mortal fear, syncope (19\%), low blood pressure, haemodynamic failure with large vessel obstruction, arrhythmia (atrial or ventricular extrasystole, acute atrial fibrillation, flutter, etc.) (Miniati, Prediletto, Formichi, Marini, Di Ricco, Tonelli, Allescia \& Pistolesi, 1999a; Stein \& Henry, 1997).

\subsubsection{Chest X-ray}

According to the PISAPED study, occlusion of the hilar artery, oligaemia, wedge shaped infiltration against the pleural wall is detectable in 15-45\% of all cases (Miniati, Prediletto, Formichi, Marini, Di Ricco, Tonelli, Allescia \& Pistolesi, 1999b). In acute PE the typical X-ray signs can be weak or absent, but a single-sided elevation of the diaphragm, stripe-like atelectasis and the oedema of the affected pulmonary tissue (Westermark-sign) may develop with the prominence of the pulmonary artery. Occasionally unilateral pleural effusion is present. Chest $\mathrm{X}$-ray is useful to exclude certain diagnoses.

\subsubsection{Electrocardiography (ECG)}

The most common alterations are: sinus tachycardia, $\mathrm{S}_{1} \mathrm{Q}_{3} \mathrm{~T}_{3}$ waveform (McGinn-White syndrome), acute $\mathrm{P}$-pulmonale, negative $\mathrm{T}$ waves in $\mathrm{V}_{1-3}$ leads, incomplete or complete right bundle branch block, signs of RV strain, acute atrial fibrillation, atrio-ventricular conduction failures. Enlarged $\mathrm{S}_{\mathrm{I}} \mathrm{S}_{\mathrm{II}} \mathrm{S}_{\mathrm{III}}$ waveform develops after the dilatation of the right cavities causing the rotation of the cardiac axis. ECG signs are positive only in 50\% of all patients (Torbicki et al., 2000; Torbicki et al., 2008; Geibel et al., 2005; Rodger, Makropoulos, et al., 2000).

\subsubsection{Perfusion scintigraphy}

Multiple studies have confirmed the benefit of perfusion scintigraphy as a non-invasive diagnostic procedure. It is necessary to combine perfusion scintigraphy with additional radiology imaging, like ventilation scintigraphy or chest X-ray. Various studies have confirmed that ventilation-perfusion scintigraphy has a positive predictive value of $88 \%$ (The PIOPED Investigators, 1990; Lee et al., 2005). The PISAPED study divided the probability of PE into 3 groups based on chest X-ray and perfusion scintigraphy results (Miniati et al., 1996). The sensitivity of perfusion scintigraphy is $92 \%$ with a positive predictive value of $92 \%$. It has a negative predictive value of $88 \%$ with the specificity of $87 \%$. Chronic pulmonary diseases caused perfusion defects may produce PE characteristic false results. To sum up, scintigraphy can help to exclude PE (error rate: $0.9 \%$, confidence interval: $2.3 \%$ ) (Kruip et al., 2003).

\subsubsection{Angiography}

According to the most recent PE guideline, the use of angiography is questionable as an invasive and hazardous intervention with mortality rate of $0.2 \%$. The use of angiography is 
recommended in case of uncertain radiological imaging results. Non-invasive CT angiography offers comparable or better sensitivity (Wan et al., 2004; Agnelli et al., 2002).

\subsubsection{Computed tomography, multidetector computed tomography (MDCT)}

The MDCT is a non-invasive approach, replacing angiography without the need of central venous access. It has a sensitivity of $83 \%$ and specificity of $96 \%$. The negative predictive value of MDCT for PE is $89 \%$ in the intermediate and $96 \%$ in the low clinical risk groups. The cost-benefit and cost-life ratio increases significantly with the combination of MDCT and D-dimer assessment (Perrier et al., 2004; van Belle et al., 2006). With MDCT imaging one can visualise pulmonary vasculature up to the segmental level. An MDCT result showing a PE up to the segmental level could be taken as firm evidence (Eyer et al., 2005; Brunot et al., 2005; Righini et al., 2008; Ghaye et al., 2001; Perrier et al., 2004).
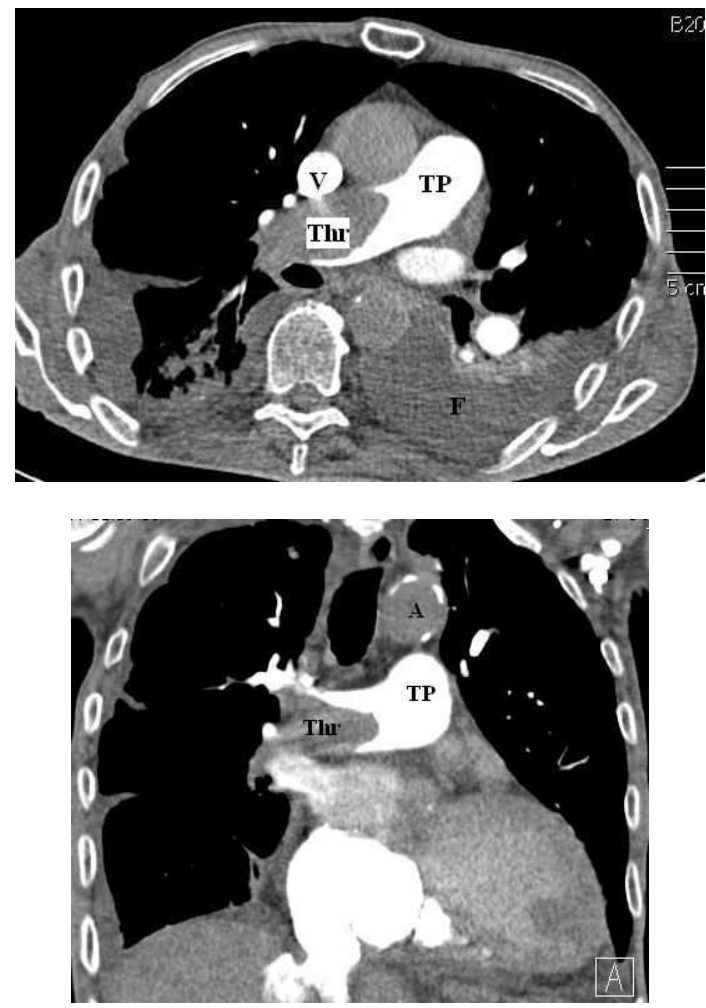

Fig. 1. Computed tomography image of acute pulmonary embolism.

(From authors own collection. A: aorta, TP: pulmonary trunk, F: thoracic effusion, Thr: clot)

\subsubsection{Echocardiography}

Transthoracic echocardiography

Echocardiography is a useful bedside non-invasive procedure in the differential diagnosis of various conditions (acute myocardial infarction, aortic dissection, pericardial tamponade, 
chest pain, valve dysfunction, hypovolaemia). The sensitivity of echocardiography is about $60-70 \%$ in PE. Negative results do not exclude PE. Acute massive PE has characteristic echocardiography signs: RV hypokinesis and/or dilatation, the end diastolic diameter of the $\mathrm{RV}$ in the parasternal short axis $>30 \mathrm{~mm}$, or RV/LV end diastolic diameter ratio $>0.9$, in the apical or subcostal axis, D-sign, increased pulmonary arterial pressure, dilatation of the inferior caval vein. A heart cavity thrombus, patent foramen ovale (with the risk of paradox thrombi), tricuspidal valve thrombosis or vegetation and floating clot in the right ventricle can also be visualised.

The positive echocardiographic result has a predictive value in haemodynamically stable patient, as the intermediate risk group has worse outcome (Konstantinides, 2008; Torbicki et al., 2003; Ferrari et al., 2005; Hsiao et al., 2006; Casazza et al., 2005; Bova et al., 2003; Miniati et al., 2001; Roy et al., 2005; Konstantinides et al., 1998).

Transoesophageal echocardiography

The transoesophageal echocardiography is a semi-invasive diagnostic procedure, which can be useful in mechanically ventilated patients. Benefits of the transoesophageal approach are: visualisation of thrombi in the pulmonary trunk and/or main pulmonary arteries and also in the caval vein. Possible tumours originating from the heart or floating into the cavities of the heart can also be visualised (Sanchez et al., 2008).

\subsubsection{The diagnosis of DVT}

With duplex ultrasound the clot is visible as a hyperechogenic signal. The procedure has 9598\% specificity. The sensitivity for PE is rather low, only $30-50 \%$ of PE cases present DVT with ultrasonography (Lee et al., 2005). The only validated verification method is the incomplete compressibility of the vein indicating the presence of the clot (Goldhaber \& Morrison, 2002; Lee et al., 2005; Le Gal et al., 2006).

Although extremity CT can also aid the diagnosis of DVT, the increased irradiation, need of contrast agent and elevated costs contraindicate the use of CT scan in all cases (Brenner \& Hall, 2007).

\subsubsection{Laboratory diagnostics}

Arterial blood gas analysis: Hypocapnia with hypoxaemia is characteristic for PE. About $20 \%$ of patients have a normal arterial oxygen tension and normal alveolar-arterial oxygen gradient (Rodger, Carrier, et al., 2000; Stein et al., 1996).

D-dimer is a fibrin degradation product. Quantitative ELISA or ELISA-like methods are 99\% sensitive, if D-dimer concentration is above $500 \mu \mathrm{g} / \mathrm{l}$. According to Dunn et al. the sensitivity for PE is $96.4 \%$, with a negative predictive value of $99.6 \%$, specificity $52.0 \%$ and positive predictive value $9.5 \%$. Although the measurement is specific for fibrin, but the specificity of fibrin for VTE is considerably lower, the summarized specificity is only 40$65 \%$. The D-dimer test can be positive in the following diseases: infections, tumours, necrosis, pregnancy, postnatal, postoperative state, sepsis, etc., therefore, it cannot be used generally. In emergency situations, the D-dimer test is useful to exclude PE from differential diagnosis. Segal recommended the inclusion of D-dimer into the Geneva and Wells score systems (Dunn et al., 2002; Segal, Eng, et al., 2007; Spannagl et al., 2005; Reber et al., 2004; van Belle et al., 2006).

Cardiac troponin $T$ and B-type natriuretic peptide (BNP): Increased cardiac troponin and BNP levels are good indicators of impaired RV function. About $11-50 \%$ of PE patients show 
increased marker levels. Echocardiography results correlate showing a decreased RV function. Negative troponin results are good predictors of favourable outcome. Both markers are useful and independent predictors of the 30 days mortality. Impaired RV function with increased troponin and BNP are relative indications of thrombolysis (TL) therapy in the intermediate risk group (Giannitsis et al., 2000; Kostrubiec et al., 2005; Krüger et al., 2004; ten Wolde et al., 2004; Worth, 2009). The recommended therapeutic approach according to Kucher and Goldhaber based on these data (Kucher \& Goldhaber, 2003):
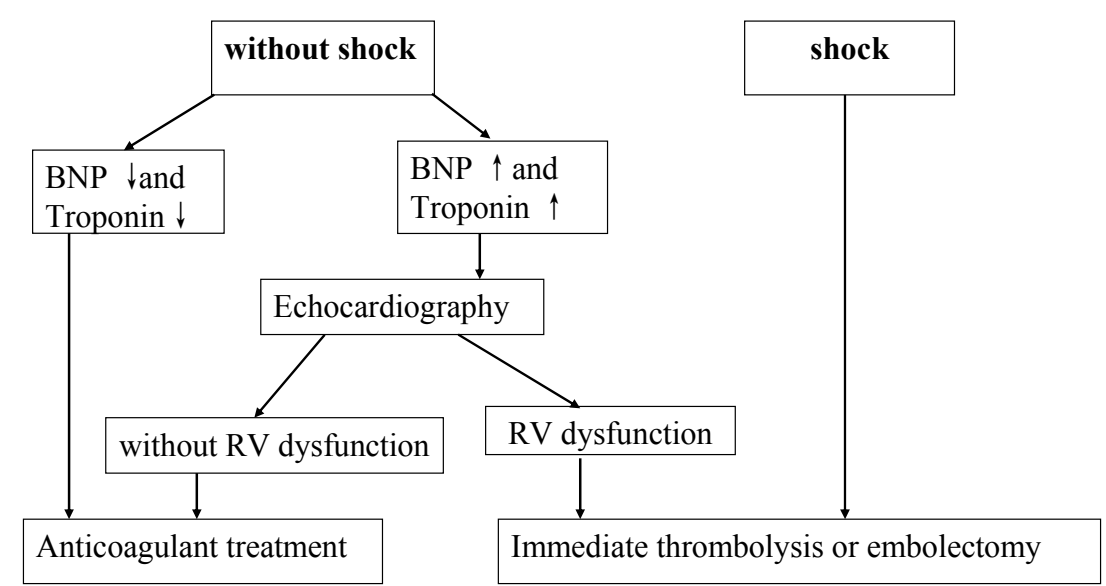

Fig. 2. Kucher and Goldhaber recommendation for the treatment of pulmonary embolism based on biomarkers and echocardiography.

Cases with severe haemodynamic shock present elevated lactate and metabolic acidosis due to global microcirculatory impairment and tissue hypoxaemia. These markers can predict poor outcome.

According to the recent guidelines, the diagnosis of PE is mainly based on the results of echocardiography, MDCT and biomarkers (Torbicki et al., 2008).

\subsection{Therapy}

\subsubsection{Acute therapy}

For main therapeutic recommendations, we follow the ESC 2008 guidelines (Torbicki et al., 2008). Anticoagulation therapy should be initiated upon suspicion of PE. 5000 IU Na-heparin is recommended as intravenous bolus if the patient had not already received Low Molecular Weight Heparin (LMWH) previously. Besides providing secure venous access, patients should receive immediate oxygen therapy through a $50 \%$ or $100 \%$ face mask. The indication of oxygen therapy is absolute, but mechanical ventilation should be used with caution. Mechanical ventilation may decrease the venous reflow and increases RV insufficiency, therefore, low tidal volume $(7 \mathrm{ml} / \mathrm{kg})$ ventilation and intravenous fluid therapy is recommended. The alveolar-arterial gas exchange can also be impaired as shunt-flow and cardiac output decrease (Singer, M; Webb, 2004; Sevransky et al., 2004). Capnometry is highly recommended during mechanical ventilation, as it may change due to thrombolysis 


\section{High risk PE (Shock/hypotension)}

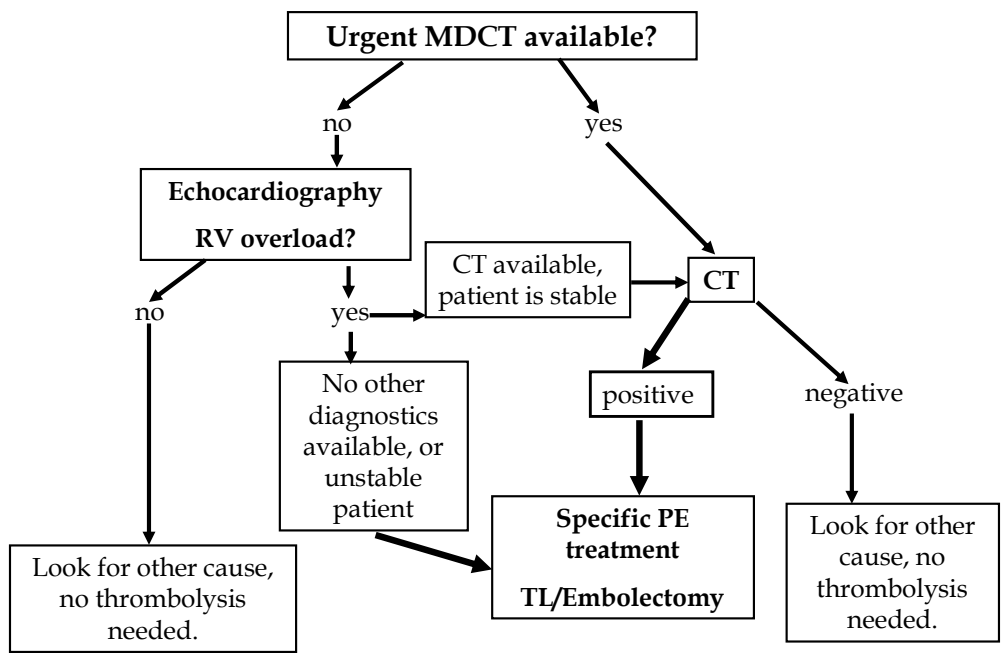

Fig. 3. The ESC 2008 guideline recommended diagnostic steps for high risk PE patients

\section{Non-high risk PE (without Shock or hypotension)}

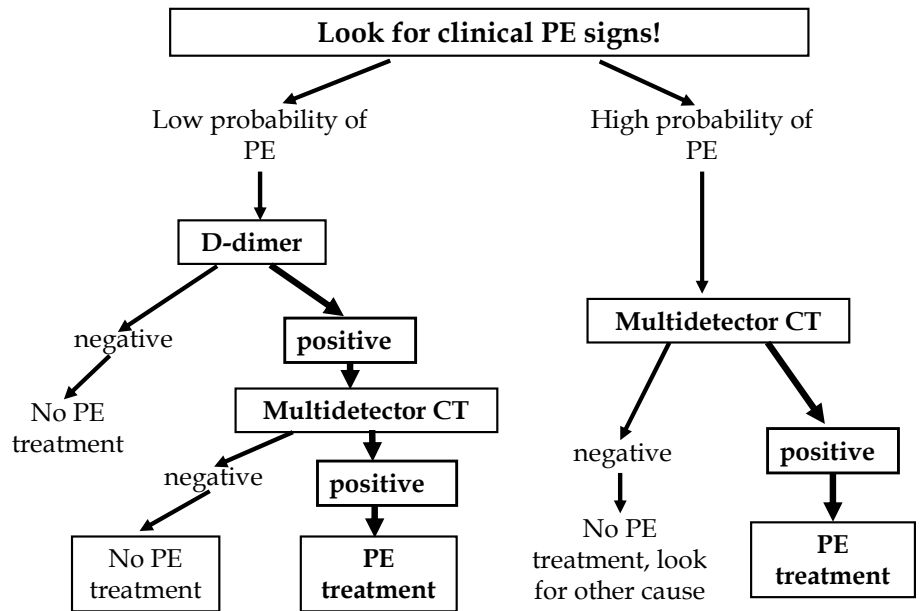

Fig. 4. The ESC 2008 guideline recommended diagnostic steps for non-high risk PE patients

or re-embolism. Morphine (or other opiate analgesic) can be administered as repeated intravenous bolus of $2 \mathrm{mg}$ for analgesia. To achieve optimal haemorheological parameters and a desirable volume state, aggressive fluid resuscitation must be carried out intravenously in the acute phase (crystalloid $1.5-2 \mathrm{ml} / \mathrm{kg} / \mathrm{h}$ ). Early fluid resuscitation is recommended based on hypotension from the loss of LV end diastolic volume. Ozier et al. 
measured the effect of $600 \mathrm{ml}$ crystalloid infusion and found an increase of cardiac index from 1.7 to $2.0 \mathrm{l} / \mathrm{min} / \mathrm{m}^{2}$. Also, Mercat et al. found the same increase of cardiac index after the infusion of $500 \mathrm{ml}$ dextrane. Modest fluid challenge is recommended, as fluid overload may depress contractility and decrease cardiac output (Kasper et al., 1997; Mercat et al., 1999; Ozier et al., 1984). If bronchospasm develops $200 \mathrm{mg}$ intravenous theophyllin may be administered. If required, norepinephrine and/or dobutamine are the choice of positive inotropic drugs. Norepinephrine improve RV function with direct effect on contractility (Prewitt, 1990). Büchner primary recommends norepinephrine and dobutamine combination for haemodynamic shock (S. Büchner \& Th. Hachenberg, 2005).

Elevated lactate levels indicate capillary perfusion impairment. The normalisation of lactate shows the resolution of the haemodynamic failure. Also, a radial arterial line is useful for continuous blood pressure monitoring and to draw frequent blood samples upon the verification of high-risk or non high-risk PE. Pulse contour cardiac output systems, like the "PiCCO"-system (Pulsion Medical Inc., Germany) is capable of continuous haemodynamic monitoring including cardiac output. Phosphodiesterase-III inhibitors (i.e. enoximon) and Ca-channel sensitizers (i.e. levosimendan) may have a beneficial effect, but insufficient clinical evidence is available yet (Nowak et al., 2007; Kerbaul et al., 2007). Also, the inhalation of nitrous oxide may improve the gas exchange of patients with PE (Torbicki et al., 2008).

If deep vein Doppler ultrasound suspects a floating, weak structure clot, thus reembolisation may occur, a temporary placement of caval vein filter should be considered before TL.

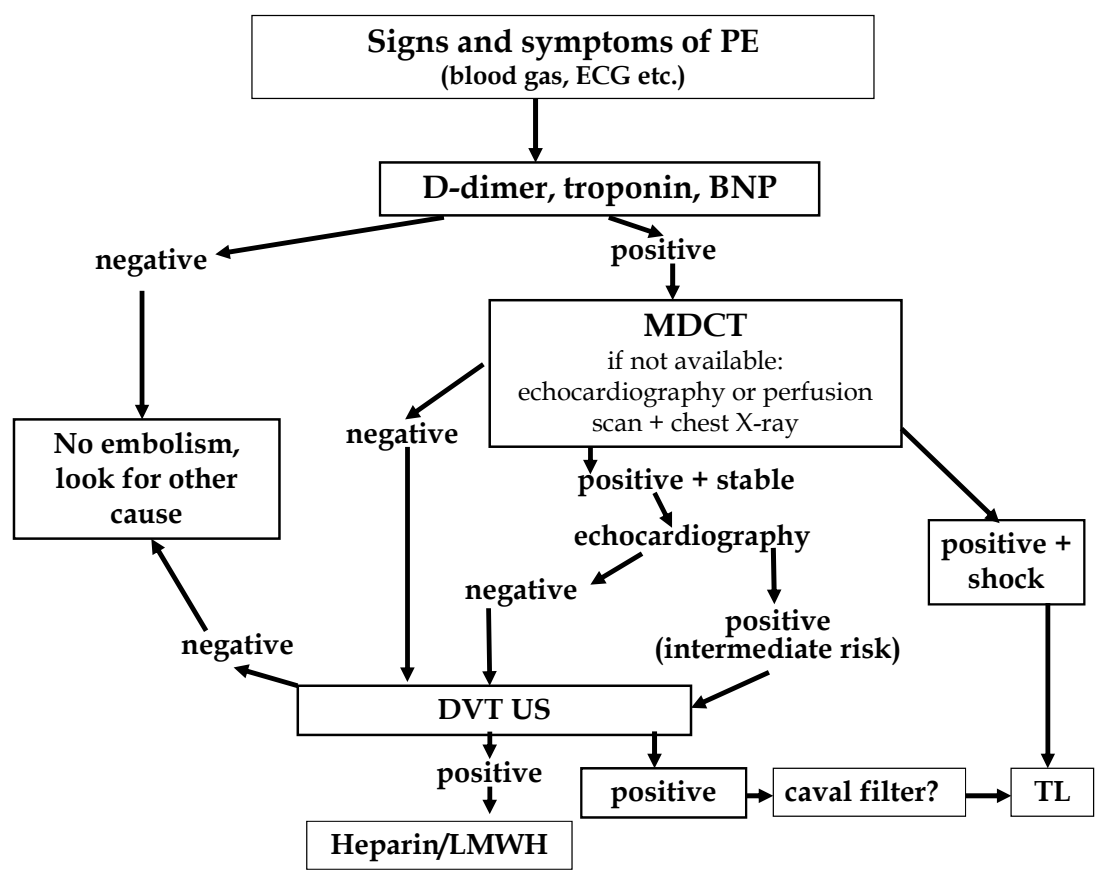

Fig. 5. The authors' own diagnostic and therapeutic approach (US: ultrasound) 


\subsubsection{Thrombolysis}

Based on this complex classification a planned approach is essential. The aim of the management of acute severe PE is the resolution of the pulmonary artery obstruction. The most common procedure is TL, but invasive radiology procedures (clot fragmentation and vacuum evacuation, or selective TL through catheter arteriography, Class IIb C) or acute surgical embolectomy (Class I C) can also remove PE.

In critical patients with severe shock and confirmed PE the indication of urgent systemic TL is absolute (Class I A). The recommended medications and appropriate dosage is available in the current PE guideline (Table 3). The authors support the accelerated TL (rt-PA or SK) protocol in haemodynamically instable patients. According to our experience the ultra-high dose streptokinase is an economically reasonable and effective alternative to rt-PA (Sárosi et al., 1997; Sárosi et al., 1995).

\begin{tabular}{|l|l|l|}
\hline Medication & Continuous TL & Accelerated TL \\
\hline streptokinase (SK) & $\begin{array}{l}250,000 \mathrm{IU} / 30 \mathrm{~min}, \text { following } \\
100,000 \mathrm{IU} / \mathrm{h} \text { for } 12-24 \text { hours }\end{array}$ & $1.5 \mathrm{IU} / 2$ hours \\
\hline urokinase (UK) & $\begin{array}{l}4,400 \mathrm{IU} / \mathrm{kg} / 10 \mathrm{~min}, \text { following } \\
4,400 \mathrm{IU} / \mathrm{kg} / \mathrm{h} \text { for } 12-24 \text { hours }\end{array}$ & $3 \mathrm{IU} / 2$ hours \\
\hline rt-PA & $100 \mathrm{mg} / 2$ hours & $\begin{array}{l}0.6 \mathrm{mg} / \mathrm{kg} / 15 \mathrm{~min} \\
(\mathrm{max}: 50 \mathrm{mg})\end{array}$ \\
\hline
\end{tabular}

Table 3. Recommended thrombolytic regimens (Torbicki et al., 2008)

In the intermediate-risk group, with main arterial embolism and increased RV load, positive D-sign, elevated troponin and BNP levels but without haemodynamical impairment, TL is recommended only after considering relative contraindications and acquisition of written informed consent (Class IIb B).

Certain patient history absolutely contraindicates TL: haemorrhagic stroke, or stroke of unconfirmed origin, ischemic stroke in the last 6 months, central nervous system tumour, neuro, trauma, or general surgery intervention in the last 3 weeks, gastrointestinal bleeding in the last 30 days, known bleeding, or bleeding disorder.

The relative contraindications are: transient ischemic attack in the last 6 months, oral anticoagulation (vitamin $\mathrm{K}$ antagonists), pregnancy and the $1^{\text {st }}$ week following labour, organ biopsy and non-compressible puncture, traumatic resuscitation, critical hypertension $\left(\mathrm{RR}_{\mathrm{s}}>180 \mathrm{mmHg}\right)$, advanced liver disease, infective endocarditis, active peptic ulcer (Torbicki et al., 2008). In life-threatening situations, every contraindication can be considered to be relative.

The effectiveness of TL should be controlled between 12 and 24 hours by a second look MDCT or other available diagnostic procedure (perfusion lung scan or echocardiography). If the decrease of unperfused area does not improve by $30 \%$ following the first treatment cycle, TL should be repeated after 24 hours.

During resuscitation, chest compressions assist the mechanical fragmentation of clot and improve the infiltration of drugs into the clot. Urokinase 2-3 MIU, rt-PA $2 \times 50 \mathrm{mg}$ or streptokinase 1.5 MIU (may repeat once after 15 minutes) can be used for TL. Compressions should continue for at least 90 minutes during TL. As TL is beneficial in PE and also in acute myocardial infarction, no firm diagnostic evidence is needed for the treatment (Böttiger \& Spöhr, 2003). One main advantage of TL is the possibility of prompt use and that it may improve overall microcirculation (Böttiger \& Martin, 2001). 
Based on our previous clinical investigations, in case of bleeding complications the repetitive measurement of clot formation factors (namely fibrinogen and plasminogen) may indicate the need of specific factor replacement or fresh frozen plasma infusion during or following TL. Major bleeding complications can be reduced below 5\%, if factor replacement takes place in patients with fibrinogen levels below $1.5 \mathrm{~g} / 1$ accompanied by minor bleeding disorder or fibrinogen levels < $0.6 \mathrm{~g} / 1$ (Mühl et al., 2007).

Patients may not benefit from the TL of a more than 5-7 days old clot. Also, a second unsuccessful TL may indicate the presence of an older, connective tissue rich clot. Invasive radiology clot fragmentation and removal with or without selective TL should be used in these scenarios.

Anticoagulation therapy during TL: In the rt-PA group unfractionated heparin is recommended during TL (500-1000 IU/h, based on actual partial thromboplastin time (aPTT) levels on admission) (Segal, Streiff, et al., 2007).

Anticoagulation therapy after TL: Anticoagulant therapy starts after strepto- or urokinase TL with intravenous unfractionated heparin to maintain aPTT (check every 4 hours!) between 50-70 seconds for the first 48 hours and continues with a therapeutic dose of LMWH, if no further TL cycle is necessary. Using the "Heparin adjustment nomogram", the dose of Naheparin is adjusted to reach a target aPTT (Torbicki et al., 2008).

Anticoagulant therapy should be provided with intravenous unfractionated heparin to maintain the aPTT between 60-70 seconds for 48 hours. If TL was effective it should be continued with a therapeutic dose of LMWH. Following TL, long term anticoagulation (acenocoumarol or warfarin) can start on day 3 or 4 (Torbicki et al., 2008; Kearon et al., 2008). In case of unfractioned heparin use, the incidence of HIT is 1-3\% (about 1\% with LMWH), therefore regular platelet count check is recommended (Greinacher, 2009; Morris et al., 2007). In case of confirmed HIT, one should switch from heparin/LMWH therapy to: hirudin, lepirudin, danaparoid or fondaparinux.

One of the most common complication of TL is minor bleeding (arterial/venous port bleeding, haematuria, suffusions, e.t.c.), major bleeding occurs in $13 \%$ of cases. The incidence of intracranial haemorrhage is 1.8\% (Spöhr et al., 2005), (Konstantinides et al., 2002; Goldhaber et al., 1993).

\subsubsection{Catheter extraction and surgical embolectomy}

Indications of percutaneous catheter embolectomy and fragmentation are unsuccessful systemic TL, contraindicatons of systemic lysis, PE with haemodynamic shock (resuscitation, mechanical ventilation), clot in the right heart, and also an alternative for the surgical embolectomy if no experienced team is available (Kucher et al., 2005; Uflacker, 2001).

Surgical embolectomy has a high mortality rate in the high-risk PE group. Indications are narrow, only patients with absolute systemic TL contraindications and in the absence of consent for TL may benefit from surgical intervention (Meneveau et al., 2006). Previous unsuccessful TL is not a contraindication for surgical embolectomy (Aklog et al., 2002).

\subsubsection{Intravenous (caval) filter}

Statistically there is no firm evidence of improved 12 days mortality of the caval filter use. Transient caval filters may be used up to 14 days. Late complications include migration and device thrombosis. Indications are not general; the main indication is suspected 
reoccurrence of PE and contraindication of long-term anticoagulation (Hann \& Streiff, 2005). Also, venous filters for PE prophylaxis may be beneficial in trauma patients, but further studies are required to draw firm clinical evidence (Rajasekhar et al., 2011).

\subsubsection{Follow-up after PE therapy}

Following PE therapy, a switch from heparin/LMWH to oral anticoagulation is recommended. Oral anticoagulation should be continued for 6 months. Following, an extended diagnostic procedure should take place to elucidate possible genetic factors or acquired thrombophylia behind the development of PE. In case of irreversible complications or positive thrombotic predisposition, continuous oral anticoagulation is needed (Kearon et al., 2008).

\section{A new approach to PE}

\subsection{The role of matrix metalloproteinases}

Experimental evidence indicated that the pathophysiology of PE implies the activation of matrix metalloproteinases (MMPs) (Uzuelli et al., 2008; Dias-Junior et al., 2009; Souza-Costa et al., 2005; Souza-Costa et al., 2007; Palei et al., 2005; Fortuna et al., 2007). Indeed, hemodynamic derangements associated with this condition improved with the inhibition of MMPs. Neutrophil activation (Eagleton et al., 2002) and rapid release of granules containing large amounts of MMP-9 in inflammation (Van den Steen et al., 2002) and during PE explains how MMPs, especially MMP-9, are involved in pathophysiology of PE. The increased activity and levels of MMP-9 found in ischemic stroke, or the upregulation of the enzyme after cerebral ischemia are interestingly similar to PE (Asahi et al., 2000). The degradation of type IV collagen, laminin, and fibronectin by MMP-9, may contribute to hemorrhagic transformation after cardioembolic stroke as these components are the main structure of the vascular matrix (Rosell et al., 2008; Montaner et al., 2001). Also, tissue plasminogen activator (or alteplase) can amplify MMP-9 levels by upregulation, thus increasing ischemic brain damage (Wang et al., 2004; Burggraf et al., 2007; Ning et al., 2006; Tsuji et al., 2005). There is evidence, that increased plasmin concentration may activate MMPs. Previous experimental work by our group aimed to assess the levels of MMPs following fibrinolysis for acute PE. Circulating levels of MMPs were measured serially (MMP-9 and MMP-2). Their endogenous inhibitors, tissue inhibitor of metalloproteinase (TIMP)-1 and TIMP-2 were also measured in alteplase and in ultra-high dose streptokinase-treated patients with acute PE (Mühl et al., 2010).

\subsection{Measurements and discussion of TIMP/MMP changes in PE}

In our study MMP levels were assessed by sodium-dodecil-sulphate polyacrylamide gel electrophoresis, TIMP levels were measured with a commercially available ELISA kit (Mühl et al., 2010). Significant increases in pro-MMP-9 concentrations were found after TL therapy in both groups, but these were not associated with significant alterations in TIMP-1 levels. Pro-MMP-9/TIMP-1 ratio increased significantly. Interestingly, earlier increases in proMMP-9 levels and in pro-MMP-9/TIMP-1 ratio were found in subjects treated with streptokinase. From the $3^{\text {rd }}$ day pro-MMP-9 levels and pro-MMP-9/TIMP-1 ratio returned to normal. No significant changes in pro-MMP-2 concentrations were measured after TL. Moreover, we found no significant changes in TIMP-2 concentrations or in pro-MMP2/TIMP-2 ratio. 
Although there is a lack of firm evidence, the possible explanation for increased MMP-9 levels during treatment with alteplase is the promotion of MMP-9 release by neutrophils (Cuadrado et al., 2008). According to our knowledge, no previous study has reported that streptokinase induces the release of MMP-9.

A slower increase of pro-MMP-9 was found in alteplase treated patients, but the precise explanation for this difference between fibrinolytic agents is not yet elucidated. There is significant interindividual variability in neutrophil degranulation (Cuadrado et al., 2008), therefore a multi-central study may draw firm evidence on this question.

No definitive conclusion can be drawn yet, but it is widely acknowledged that intracerebral hemorrhage is the most feared bleeding complication of TL (Arcasoy \& Kreit, 1999). The use of alteplase enhanced MMP-9 levels, which has already been widely associated with hemorrhagic transformation after cardioembolic stroke (Rosell et al., 2008; Montaner et al., 2001). This observation offers an explanation for the hemorrhagic transformation during stroke.

It is possible that the MMP inhibitors may decrease the risk of intracerebral hemorrhage or other bleeding complication of TL for acute PE (Murata et al., 2008; Sumii \& Lo, 2002; Machado et al., 2009) and may have beneficial hemodynamic effects (Fortuna et al., 2007; Palei et al., 2005).

\section{Summary}

Following risk stratification, prompt and specific diagnostics are life-saving in acute PE. Recommended diagnostic tools are biomarkers, MDCT and electrocardiography. Systemic $\mathrm{TL}$ is the first choice for high-risk PE patients, in case of contraindications surgical embolectomy or catheter clot fragmentation/removal should be considered. The fast resolution of haemodynamic shock indicates accelerated protocol systemic TL (rt-PA, SK or UK), as continuous TL dissolve clot slower and have a higher risk of bleeding disorder. The regular control of fibrinogen and plasminogen during and after TL, and clot formation factor supplement can reduce bleeding complications.

There is emerging evidence of the hypothesized role of the TIMP/MMP system in the development of bleeding complication. In future, pharmacological approach to MMP inhibition in human medicine may decrease the incidence of bleeding complications of TL.

\section{References}

Ageno, W., Squizzato, A., Garcia, D. \& Imberti, D. (2006). Epidemiology and risk factors of venous thromboembolism. Seminars in thrombosis and hemostasis, Vol.32, No.7, (April 2007), pp. 651-8, ISSN 0094-6176

Agnelli, G., Becattini, C. \& Kirschstein, T. (2002). Thrombolysis vs heparin in the treatment of pulmonary embolism: a clinical outcome-based meta-analysis. Archives of internal medicine, Vol.162, No.22, (December 2002), pp. 2537-41, ISSN 0003-9926

Aklog, L., Williams, C.S., Byrne, J.G. \& Goldhaber, S.Z. (2002). Acute pulmonary embolectomy: a contemporary approach. Circulation, Vol.105, No.12, (March 2002), pp. 1416-9, ISSN 1524-4539

Arcasoy, S.M. \& Kreit, J.W. (1999). Thrombolytic therapy of pulmonary embolism: a comprehensive review of current evidence. Chest, Vol.115, No.6, (June 1999), pp. 1695-707, ISSN 0012-3692 
Asahi, M., Asahi, K., Jung, J.C., del Zoppo, G.J., Fini, M.E. \& Lo, E.H. (2000). Role for matrix metalloproteinase 9 after focal cerebral ischemia: effects of gene knockout and enzyme inhibition with BB-94. Journal of cerebral blood flow and metabolism: official journal of the International Society of Cerebral Blood Flow and Metabolism, Vol.20, No.12, (December 2000), pp. 1681-9, ISSN 0271-678X

Bova, C., Greco, F., Misuraca, G., Serafini, O., Crocco, F., Greco, A. \& Noto, A. (2003). Diagnostic utility of echocardiography in patients with suspected pulmonary embolism. The American journal of emergency medicine, Vol.21, No.3, (May 2003), pp. 180-3, ISSN 0735-6757

Brenner, D.J. \& Hall, E.J. (2007). Computed tomography--an increasing source of radiation exposure. The New England journal of medicine, Vol.357, No.22, (November 2007), pp. 2277-84, ISSN 1533-4406

Brunot, S., Corneloup, O., Latrabe, V., Montaudon, M. \& Laurent, F. (2005). Reproducibility of multi-detector spiral computed tomography in detection of sub-segmental acute pulmonary embolism. European radiology, Vol.15, No.10, (October 2005), pp. 205763, ISSN 0938-7994

Burggraf, D., Martens, H.K., Dichgans, M. \& Hamann, G.F. (2007). Matrix metalloproteinase (MMP) induction and inhibition at different doses of recombinant tissue plasminogen activator following experimental stroke. Thrombosis and haemostasis, Vol.98, No.5, (November 2007), pp. 963-9, ISSN 0340-6245

Böttiger, B.W. \& Martin, E. (2001). Thrombolytic therapy during cardiopulmonary resuscitation and the role of coagulation activation after cardiac arrest. Current opinion in critical care, Vol.7, No.3, (June 2001), pp. 176-83, ISSN 1070-5295

Böttiger, B.W. \& Spöhr, F. (2003). The risk of thrombolysis in association with cardiopulmonary resuscitation: no reason to withhold this causal and effective therapy. Journal of internal medicine, Vol.253, No.2, (February 2003), pp. 99-101, ISSN 0954-6820

Büchner S., Pfeiffer B., Hachenberg T. (2005). Lungenembolie (CME 1/2/2005). Anesth. Intensivmed., No.46, (2005), pp. 9-22.

Casazza, F., Bongarzoni, A., Capozi, A. \& Agostoni, O. (2005). Regional right ventricular dysfunction in acute pulmonary embolism and right ventricular infarction. European journal of echocardiography: the journal of the Working Group on Echocardiography of the European Society of Cardiology, Vol.6, No.1, (January 2005), pp. 11-4, ISSN 1525-2167

Cuadrado, E., Ortega, L., Hernández-Guillamon, M., Penalba, A., Fernández-Cadenas, I., Rosell, A. \& Montaner, J. (2008). Tissue plasminogen activator (t-PA) promotes neutrophil degranulation and MMP-9 release. Journal of leukocyte biology, Vol.84, No.1, (July 2008), pp. 207-14, ISSN 0741-5400

Dahlbäck, B. (1995). Inherited thrombophilia: resistance to activated protein C as a pathogenic factor of venous thromboembolism. Blood, Vol.85, No.3, (February 1995), pp. 607-14, ISSN 0006-4971

Demers, C., Ginsberg, J.S., Hirsh, J., Henderson, P. \& Blajchman, M.A. (1992). Thrombosis in antithrombin-III-deficient persons. Report of a large kindred and literature review. Annals of internal medicine, Vol.116, No.9, (May 1992), pp. 754-61, ISSN 0003-4819

den Heijer, M., Koster, T., Blom, H.J., Bos, G.M., Briet, E., Reitsma, P.H., Vandenbroucke, J.P. \& Rosendaal, F.R. (1996). Hyperhomocysteinemia as a risk factor for deep-vein 
thrombosis. The New England journal of medicine, Vol.334, No.12, (March 1996), pp. 759-62, ISSN 0028-4793

Dias-Junior, C.A., Cau, S.B.A., Oliveira, A.M., Castro, M.M., Montenegro, M.F., Gerlach, R.F. \& Tanus-Santos, J.E. (2009). Nitrite or sildenafil, but not BAY 41-2272, blunt acute pulmonary embolism-induced increases in circulating matrix metalloproteinase-9 and oxidative stress. Thrombosis research, Vol.124, No.3, (January 2009), pp. 349-55, ISSN 1879-2472

Dunn, K.L., Wolf, J.P., Dorfman, D.M., Fitzpatrick, P., Baker, J.L. \& Goldhaber, S.Z. (2002). Normal D-dimer levels in emergency department patients suspected of acute pulmonary embolism. Journal of the American College of Cardiology, Vol.40, No.8, (October 2002), pp. 1475-8, ISSN 0735-1097

Eagleton, M.J., Henke, P.K., Luke, C.E., Hawley, A.E., Bedi, A., Knipp, B.S., Wakefield, T.W. \& Greenfield, L.J. (2002). Southern Association for Vascular Surgery William J. von Leibig Award. Inflammation and intimal hyperplasia associated with experimental pulmonary embolism. Journal of vascular surgery: official publication, the Society for Vascular Surgery [and] International Society for Cardiovascular Surgery, North American Chapter, Vol.36, No.3, (September 2002), pp. 581-8, ISSN 0741-5214

Eyer, B.A., Goodman, L.R. \& Washington, L. (2005). Clinicians' response to radiologists' reports of isolated subsegmental pulmonary embolism or inconclusive interpretation of pulmonary embolism using MDCT. AJR. American journal of roentgenology, Vol.184, No.2, (February 2005), pp. 623-8, ISSN 0361-803X

Ferrari, E., Benhamou, M., Berthier, F. \& Baudouy, M. (2005). Mobile thrombi of the right heart in pulmonary embolism: delayed disappearance after thrombolytic treatment. Chest, Vol.127, No.3, (March 2005), pp. 1051-3, ISSN 0012-3692

Fortuna, G.M., Figueiredo-Lopes, L., Dias-Junior, C.A.C., Gerlach, R.F. \& Tanus-Santos, J.E. (2007). A role for matrix metalloproteinase- 9 in the hemodynamic changes following acute pulmonary embolism. International journal of cardiology, Vol.114, No.1, (January 2007), pp. 22-7, ISSN 1874-1754

Geibel, A., Zehender, M., Kasper, W., Olschewski, M., Klima, C. \& Konstantinides, S.V. (2005). Prognostic value of the ECG on admission in patients with acute major pulmonary embolism. The European respiratory journal: official journal of the European Society for Clinical Respiratory Physiology, Vol.25, No.5, (May 2005), pp. 843-8, ISSN 0903-1936

Ghaye, B., Szapiro, D., Mastora, I., Delannoy, V., Duhamel, A., Remy, J. \& Remy-Jardin, M. (2001). Peripheral pulmonary arteries: how far in the lung does multi-detector row spiral CT allow analysis? Radiology, Vol.219, No.3, (June 2001), pp. 629-36, ISSN 0033-8419

Giannitsis, E., Müller-Bardorff, M., Kurowski, V., Weidtmann, B., Wiegand, U., Kampmann, M. \& Katus, H.A. (2000). Independent prognostic value of cardiac troponin $\mathrm{T}$ in patients with confirmed pulmonary embolism. Circulation, Vol.102, No.2, (July 2000), pp. 211-7, ISSN 0009-7322

Goldhaber, S.Z. (1998). Pulmonary embolism. The New England journal of medicine, Vol.339, No.2, (July 1998), pp. 93-104, ISSN 0028-4793

Goldhaber, S.Z. \& Morrison, R.B. (2002). Cardiology patient pages. Pulmonary embolism and deep vein thrombosis. Circulation, Vol.106, No.12, (September 2002), pp. 1436-8, ISSN 0009-7322 
Goldhaber, S.Z., Grodstein, F., Stampfer, M.J., Manson, J.E., Colditz, G.A., Speizer, F.E., Willett, W.C. \& Hennekens, C.H. (1997). A prospective study of risk factors for pulmonary embolism in women. JAMA: the journal of the American Medical Association, Vol.277, No.8, (February 1997), pp. 642-5, ISSN 1538-3598

Goldhaber, S.Z., Haire, W.D., Feldstein, M.L., Miller, M., Toltzis, R., Smith, J.L., Taveira da Silva, A.M., Come, P.C., Lee, R.T. \& Parker, J.A. (1993). Alteplase versus heparin in acute pulmonary embolism: randomised trial assessing right-ventricular function and pulmonary perfusion. Lancet, Vol.341, No.8844, (February 1993), pp. 507-11, ISSN 0140-6736

Goldhaber, S.Z., Visani, L. \& De Rosa, M. (1999). Acute pulmonary embolism: clinical outcomes in the International Cooperative Pulmonary Embolism Registry (ICOPER). The Lancet, Vol.353, No.9162, (April 1999), pp. 1386-1389, ISSN 0140-6736

Greinacher, A. (2009). Heparin-induced thrombocytopenia. Journal of thrombosis and haemostasis: JTH, Vol.7 Suppl 1, (July 2009), pp. 9-12, ISSN 1538-7836

Hann, C.L. \& Streiff, M.B. (2005). The role of vena caval filters in the management of venous thromboembolism. Blood reviews, Vol.19, No.4, (July 2005), pp. 179-202, ISSN 0268960X

Hsiao, S.-H., Chang, S.-M., Lee, C.-Y., Yang, S.-H., Lin, S.-K. \& Chiou, K.-R. (2006). Usefulness of tissue Doppler parameters for identifying pulmonary embolism in patients with signs of pulmonary hypertension. The American journal of cardiology, Vol.98, No.5, (September 2006), pp. 685-90, ISSN 0002-9149

Janata, K., Holzer, M., Domanovits, H., Müllner, M., Bankier, A., Kurtaran, A., Bankl, H.C. \& Laggner, A.N. (2002). Mortality of patients with pulmonary embolism. Wiener klinische Wochenschrift, Vol.114, No.17-18, (September 2002), pp. 766-72, 0043-5325

Kasper, W., Konstantinides, S., Geibel, A., Olschewski, M., Heinrich, F., Grosser, K.D., Rauber, K., Iversen, S., Redecker, M. \& Kienast, J. (1997). Management strategies and determinants of outcome in acute major pulmonary embolism: results of a multicenter registry. Journal of the American College of Cardiology, Vol.30, No.5, (November 1997), pp. 1165-71, ISSN 0735-1097

Kearon, C., Kahn, S.R., Agnelli, G., Goldhaber, S., Raskob, G.E. \& Comerota, A.J. (2008). Antithrombotic therapy for venous thromboembolic disease: American College of Chest Physicians Evidence-Based Clinical Practice Guidelines (8th Edition). Chest, Vol.133, No.6 Suppl, (June 2008), p. 454S-545S, ISSN 0012-3692

Kerbaul, F., Gariboldi, V., Giorgi, R., Mekkaoui, C., Guieu, R., Fesler, P., Gouin, F., Brimioulle, S. \& Collart, F. (2007). Effects of levosimendan on acute pulmonary embolism-induced right ventricular failure. Critical care medicine, Vol.35, No.8, (August 2007), pp. 1948-54, ISSN 0090-3493

Kline, J.A., Hernandez-Nino, J., Newgard, C.D., Cowles, D.N., Jackson, R.E. \& Courtney, D.M. (2003). Use of pulse oximetry to predict in-hospital complications in normotensive patients with pulmonary embolism. The American journal of medicine, Vol.115, No.3, (August 2003), pp. 203-8, ISSN 0002-9343

Konstantinides, S. (2008). Clinical practice. Acute pulmonary embolism. The New England journal of medicine, Vol.359, No.26, (December 2008), pp. 2804-13, ISSN 0028-4793

Konstantinides, S. (2005). Pulmonary embolism: impact of right ventricular dysfunction. Current opinion in cardiology, Vol.20, No.6, (November 2005), pp. 496-501, ISSN 0268-4705 
Konstantinides, S. \& Hasenfuss, G. (2004). [Acute cor pulmonale in pulmonary embolism. An important prognostic factor and a critical parameter for the choice of a therapeutic strategy]. Der Internist, Vol.45, No.10, (October 2004), pp. 1155-62, ISSN 0020-9554

Konstantinides, S., Geibel, A., Heusel, G., Heinrich, F. \& Kasper, W. (2002). Heparin plus alteplase compared with heparin alone in patients with submassive pulmonary embolism. The New England journal of medicine, Vol.347, No.15, (October 2002), pp. 1143-50, ISSN 0028-4793

Konstantinides, S., Geibel, A., Kasper, W., Olschewski, M., Blümel, L. \& Just, H. (1998). Patent foramen ovale is an important predictor of adverse outcome in patients with major pulmonary embolism. Circulation, Vol.97, No.19, (May 1998), pp. 1946-51, ISSN 0009-7322

Kostrubiec, M., Pruszczyk, P., Bochowicz, A., Pacho, R., Szulc, M., Kaczynska, A., Styczynski, G., Kuch-Wocial, A., Abramczyk, P., Bartoszewicz, Z., Berent, H. \& Kuczynska, K. (2005). Biomarker-based risk assessment model in acute pulmonary embolism. European heart journal, Vol.26, No.20, (October 2005), pp. 2166-72, ISSN 0195-668X

Kruip, M.J.H.A., Leclercq, M.G.L., van der Heul, C., Prins, M.H. \& Büller, H.R. (2003). Diagnostic strategies for excluding pulmonary embolism in clinical outcome studies. A systematic review. Annals of internal medicine, Vol.138, No.12, (June 2003), pp. 941-51, ISSN 0003-4819

Krüger, S., Graf, J., Merx, M.W., Koch, K.C., Kunz, D., Hanrath, P. \& Janssens, U. (2004). Brain natriuretic peptide predicts right heart failure in patients with acute pulmonary embolism. American heart journal, Vol.147, No.1, (January 2004), pp. 605, ISSN 0002-8703

Kucher, N. \& Goldhaber, S.Z. (2003). Cardiac biomarkers for risk stratification of patients with acute pulmonary embolism. Circulation, Vol.108, No.18, (November 2003), pp. 2191-4 ISSN 0009-7322

Kucher, N., Windecker, S., Banz, Y., Schmitz-Rode, T., Mettler, D., Meier, B. \& Hess, O.M. (2005). Percutaneous catheter thrombectomy device for acute pulmonary embolism: in vitro and in vivo testing. Radiology, Vol.236, No.3, (September 2005), pp. 852-8, ISSN 0033-8419

Lee, C.H., Hankey, G.J., Ho, W.K. \& Eikelboom, J.W. (2005). Venous thromboembolism: diagnosis and management of pulmonary embolism. The Medical journal of Australia, Vol.182, No.11, (June 2005), pp. 569-74, ISSN 0025-729X

Le Gal, G., Righini, M., Sanchez, O., Roy, P.-M., Baba-Ahmed, M., Perrier, A. \& Bounameaux, H. (2006). A positive compression ultrasonography of the lower limb veins is highly predictive of pulmonary embolism on computed tomography in suspected patients. Thrombosis and haemostasis, Vol.95, No.6, (June 2006), pp. 963-6, ISSN 0340-6245

Machado, L.S., Sazonova, I.Y., Kozak, A., Wiley, D.C., El-Remessy, A.B., Ergul, A., Hess, D.C., Waller, J.L. \& Fagan, S.C. (2009). Minocycline and tissue-type plasminogen activator for stroke: assessment of interaction potential. Stroke; a journal of cerebral circulation, Vol.40, No.9, (September 2009), pp. 3028-33, ISSN 0039-2499

Meneveau, N., Séronde, M.-F., Blonde, M.-C., Legalery, P., Didier-Petit, K., Briand, F., Caulfield, F., Schiele, F., Bernard, Y. \& Bassand, J.-P. (2006). Management of 
unsuccessful thrombolysis in acute massive pulmonary embolism. Chest, Vol.129, No.4, (April 2006), pp. 1043-50, ISSN 0012-3692

Mercat, A., Diehl, J.L., Meyer, G., Teboul, J.L. \& Sors, H. (1999). Hemodynamic effects of fluid loading in acute massive pulmonary embolism. Critical care medicine, Vol.27, No.3, (March 1999), pp. 540-4, ISSN 0090-3493

Miniati, M., Monti, S., Pratali, L., Di Ricco, G., Marini, C., Formichi, B., Prediletto, R., Michelassi, C., Di Lorenzo, M., Tonelli, L. \& Pistolesi, M. (2001). Value of transthoracic echocardiography in the diagnosis of pulmonary embolism: results of a prospective study in unselected patients. The American journal of medicine, Vol.110, No.7, (May 2001), pp. 528-35, ISSN 0002-9343

Miniati, M., Pistolesi, M., Marini, C., Di Ricco, G., Formichi, B., Prediletto, R., Allescia, G., Tonelli, L., Sostman, H.D. \& Giuntini, C. (1996). Value of perfusion lung scan in the diagnosis of pulmonary embolism: results of the Prospective Investigative Study of Acute Pulmonary Embolism Diagnosis (PISA-PED). American journal of respiratory and critical care medicine, Vol.154, No.5, (November 1996), pp. 1387-93, ISSN 1073-449X

Miniati, M., Prediletto, R., Formichi, B., Marini, C., Di Ricco, G., Tonelli, L., Allescia, G. \& Pistolesi, M. (1999). Accuracy of clinical assessment in the diagnosis of pulmonary embolism. American journal of respiratory and critical care medicine, Vol.159, No.3, (March 1999), pp. 864-71, ISSN 1073-449X

Montaner, J., Alvarez-Sabín, J., Molina, C.A., Anglés, A., Abilleira, S., Arenillas, J. \& Monasterio, J. (2001). Matrix metalloproteinase expression is related to hemorrhagic transformation after cardioembolic stroke. Stroke; a journal of cerebral circulation, Vol.32, No.12, (December 2001), pp. 2762-7, ISSN 0039-2499

Morris, T.A., Castrejon, S., Devendra, G. \& Gamst, A.C. (2007). No difference in risk for thrombocytopenia during treatment of pulmonary embolism and deep venous thrombosis with either low-molecular-weight heparin or unfractionated heparin: a metaanalysis. Chest, Vol.132, No.4, (October 2007), pp. 1131-9, ISSN 0012-3692

Murata, Y., Rosell, A., Scannevin, R.H., Rhodes, K.J., Wang, X. \& Lo, E.H. (2008). Extension of the thrombolytic time window with minocycline in experimental stroke. Stroke; $a$ journal of cerebral circulation, Vol.39, No.12, (December 2008), pp. 3372-7, ISSN 00392499

Mühl, D., Füredi, R., Gecse, K., Ghosh, S., Falusi, B., Bogár, L., Roth, E. \& Lantos, J. (2007). Time course of platelet aggregation during thrombolytic treatment of massive pulmonary embolism. Blood coagulation $\mathcal{E}$ fibrinolysis: an international journal in haemostasis and thrombosis, Vol.18, No.7, (October 2007), pp. 661-7, ISSN 0957-5235

Mühl, D., Ghosh, S., Uzuelli, J.A., Lantos, J. \& Tanus-Santos, J.E. (2010). Increases in circulating matrix metalloproteinase-9 levels following fibrinolysis for acute pulmonary embolism. Thrombosis research, Vol.125, No.6, (June 2010), pp. 549-53, ISSN 0049-3848

Ning, M., Furie, K.L., Koroshetz, W.J., Lee, H., Barron, M., Lederer, M., Wang, X., Zhu, M., Sorensen, A.G., Lo, E.H. \& Kelly, P.J. (2006). Association between tPA therapy and raised early matrix metalloproteinase-9 in acute stroke. Neurology, Vol.66, No.10, (May 2006), pp. 1550-5, ISSN 0028-3878

Nowak, F.G., Halbfass, P. \& Hoffmann, E. (2007). [Pulmonary embolism: clinical relevance, requirements for diagnostic and therapeutic strategies]. Der Radiologe, Vol.47, No.8, (August 2007), pp. 663-72, ISSN 0033-832X 
Oger, E. (2000). Incidence of venous thromboembolism: a community-based study in Western France. EPI-GETBP Study Group. Groupe d'Etude de la Thrombose de Bretagne Occidentale. Thrombosis and haemostasis, Vol.83, No.5, (May 2000), pp. 65760, ISSN 0340-6245

Ozier, Y., Dubourg, O., Farcot, J.C., Bazin, M., Jardin, F. \& Margairaz, A. (1984). Circulatory failure in acute pulmonary embolism. Intensive care medicine, Vol.10, No.2, (1984), pp. 91-7, ISSN 0342-4642

Palei, A.C.T., Zaneti, R.A.G., Fortuna, G.M., Gerlach, R.F. \& Tanus-Santos, J.E. (2005). Hemodynamic benefits of matrix metalloproteinase- 9 inhibition by doxycycline during experimental acute pulmonary embolism. Angiology, Vol.56, No.5, (September-October 2005), pp. 611-7, ISSN 0003-3197

Perrier, A., Roy, P.-M., Aujesky, D., Chagnon, I., Howarth, N., Gourdier, A.-L., Leftheriotis, G., Barghouth, G., Cornuz, J., Hayoz, D. \& Bounameaux, H. (2004). Diagnosing pulmonary embolism in outpatients with clinical assessment, D-dimer measurement, venous ultrasound, and helical computed tomography: a multicenter management study. The American journal of medicine, Vol.116, No.5, (March 2004), pp. 291-9, ISSN 0002-9343

Poort, S.R., Rosendaal, F.R., Reitsma, P.H. \& Bertina, R.M. (1996). A common genetic variation in the $3^{\prime}$-untranslated region of the prothrombin gene is associated with elevated plasma prothrombin levels and an increase in venous thrombosis. Blood, Vol.88, No.10, (November 1996), pp. 3698-703, ISSN 0006-4971

Prewitt, R.M. (1990). Hemodynamic management in pulmonary embolism and acute hypoxemic respiratory failure. Critical care medicine, Vol.18, No.1 Pt 2, (January 1990), pp. S61-9, ISSN 0090-3493

Rajasekhar, A., Lottenberg, R., Lottenberg, L., Liu, H. \& Ang, D. (2011). Pulmonary embolism prophylaxis with inferior vena cava filters in trauma patients: a systematic review using the meta-analysis of observational studies in epidemiology (MOOSE) guidelines. Journal of thrombosis and thrombolysis, Vol.32, No.1, (July 2011), pp. 40-6, ISSN 0929-5305

Reber, G., Bounameaux, H., Perrier, A. \& De Moerloose, P. (2004). A new rapid point-of-care D-dimer enzyme-linked immunosorbent assay (Stratus CS D-dimer) for the exclusion of venous thromboembolism. Blood coagulation $\mathcal{E}$ fibrinolysis: an international journal in haemostasis and thrombosis, Vol.15, No.5, (July 2004), pp. 435-8, ISSN 0957-5235

Righini, M., Le Gal, G., Aujesky, D., Roy, P.-M., Sanchez, O., Verschuren, F., Rutschmann, O., Nonent, M., Cornuz, J., Thys, F., Le Manach, C.P., Revel, M.-P., Poletti, P.-A., Meyer, G., Mottier, D., Perneger, T., Bounameaux, H. \& Perrier, A. (2008). Diagnosis of pulmonary embolism by multidetector CT alone or combined with venous ultrasonography of the leg: a randomised non-inferiority trial. Lancet, Vol.371, No.9621, (April 2008), pp. 1343-52, ISSN 0140-6736

Rodger, M., Makropoulos, D., Turek, M., Quevillon, J., Raymond, F., Rasuli, P. \& Wells, P.S. (2000). Diagnostic value of the electrocardiogram in suspected pulmonary embolism. The American journal of cardiology, Vol.86, No.7, (October 2000), pp. 807-9, A10, ISSN 0002-9149

Rodger, M.A., Carrier, M., Jones, G.N., Rasuli, P., Raymond, F., Djunaedi, H. \& Wells, P.S. (2000). Diagnostic value of arterial blood gas measurement in suspected pulmonary 
embolism. American journal of respiratory and critical care medicine, Vol.162, No.6, (December 2000), pp. 2105-8, ISSN 1073-449X

Rosell, A., Cuadrado, E., Ortega-Aznar, A., Hernández-Guillamon, M., Lo, E.H. \& Montaner, J. (2008). MMP-9-positive neutrophil infiltration is associated to blood-brain barrier breakdown and basal lamina type IV collagen degradation during hemorrhagic transformation after human ischemic stroke. Stroke; a journal of cerebral circulation, Vol.39, No.4, (April 2008), pp. 1121-6, ISSN 0039-2499

Roy, P.-M., Colombet, I., Durieux, P., Chatellier, G., Sors, H. \& Meyer, G. (2005). Systematic review and meta-analysis of strategies for the diagnosis of suspected pulmonary embolism. British medical journal, Vol.331, No.7511, (July 2005), p. 259, ISSN 0959-8138

Sanchez, O., Trinquart, L., Colombet, I., Durieux, P., Huisman, M.V., Chatellier, G. \& Meyer, G. (2008). Prognostic value of right ventricular dysfunction in patients with haemodynamically stable pulmonary embolism: a systematic review. European heart journal, Vol.29, No.12, (June 2008), pp. 1569-77, ISSN 0195-668X

Schürmann, M., Stiegler, H., Riel, K.A. \& Schildberg, F.W. (1992). [Lung embolisms in a surgical patient sample. A retrospective study over 9 years]. Der Chirurg; Zeitschrift für alle Gebiete der operativen Medizen, Vol.63, No.10, (October 1992), pp. 811-6, ISSN 0009-4722

Segal, J.B., Eng, J., Tamariz, L.J. \& Bass, E.B. (2007). Review of the evidence on diagnosis of deep venous thrombosis and pulmonary embolism. Annals of family medicine, Vol.5, No.1, (February 2007), pp. 63-73, ISSN 1544-1709

Segal, J.B., Streiff, M.B., Hofmann, L.V., Hoffman, L.V., Thornton, K. \& Bass, E.B. (2007). Management of venous thromboembolism: a systematic review for a practice guideline. Annals of internal medicine, Vol.146, No.3, (February 2007), pp. 211-22, ISSN 0003-4819

Sevransky, J.E., Levy, M.M. \& Marini, J.J. (2004). Mechanical ventilation in sepsis-induced acute lung injury/acute respiratory distress syndrome: an evidence-based review. Critical care medicine, Vol.32, No.11 Suppl, (November 2004), pp. S548-53, ISSN 0090-3493

Singer, M; Webb, A. (2004). Pulmonary embolism. In Oxford handbook of critical care. p. 296-, ISBN 0192-6319-0X

Souza-Costa, D.C., Figueiredo-Lopes, L., Alves-Filho, J.C., Semprini, M.C., Gerlach, R.F., Cunha, F.Q. \& Tanus-Santos, J.E. (2007). Protective effects of atorvastatin in rat models of acute pulmonary embolism: involvement of matrix metalloproteinase-9. Critical care medicine, Vol.35, No.1, (January 2007), pp. 239-45, ISSN 0090-3493

Souza-Costa, D.C., Zerbini, T., Palei, A.C., Gerlach, R.F. \& Tanus-Santos, J.E. (2005). Larginine attenuates acute pulmonary embolism-induced increases in lung matrix metalloproteinase-2 and matrix metalloproteinase-9. Chest, Vol.128, No.5, (November 2005), pp. 3705-10, ISSN 0012-3692

Spannagl, M., Haverkate, F., Reinauer, H. \& Meijer, P. (2005). The performance of quantitative D-dimer assays in laboratory routine. Blood coagulation $\mathcal{E}$ fibrinolysis: an international journal in haemostasis and thrombosis, Vol.16, No.6, (September 2005), pp. 439-43, ISSN 0957-5235

Spöhr, F., Böttiger, B.W. \& Walther, A. (2005). [Errors and risks in perioperative thrombolysis therapy]. Der Anaesthesist, Vol.54, No.5, (May 2005), pp. 485-94, ISSN 0003-2417 
Stein, P.D. \& Henry, J.W. (1997). Clinical characteristics of patients with acute pulmonary embolism stratified according to their presenting syndromes. Chest, Vol.112, No.4, (October 1997), pp. 974-9, ISSN 0012-3692

Stein, P.D., Goldhaber, S.Z., Henry, J.W. \& Miller, A.C. (1996). Arterial blood gas analysis in the assessment of suspected acute pulmonary embolism. Chest, Vol.109, No.1, (January 1996), pp. 78-81, ISSN 0012-3692

Stratmann, G. \& Gregory, G.A. (2003). Neurogenic and humoral vasoconstriction in acute pulmonary thromboembolism. Anesthesia and analgesia, Vol.97, No.2, (August 2003), pp. 341-54, ISSN 0003-2999

Sumii, T. \& Lo, E.H. (2002). Involvement of matrix metalloproteinase in thrombolysisassociated hemorrhagic transformation after embolic focal ischemia in rats. Stroke; $a$ journal of cerebral circulation, Vol.33, No.3, (March 2002), pp. 831-6, ISSN 0039-2499

Sárosi, I., Mühl, D., Bogár, L., Battyányi, I., Horváth, L. \& Nemessányi, Z. (1995). [Treatment possibilities for extensive pulmonary embolism as an alternative to the Trendelenburg operation]. Orvosi hetilap, Vol.136, No.47, (November 1995), pp. 2553-9, ISSN 0030-6002

Sárosi, I., Mühl, D., Tekeres, M., Debreceni, G., Kónyi, A., Szabó, A., Farkasfalvi, K., Battyányi, I. \& Horváth, L. (1997). [Lifesaving thrombolysis--in the light of contraindications]. Orvosi hetilap, Vol.138, No.49, (December 1997), pp. 3105-9, ISSN 0030-6002

Tapson, V.F. (2008). Acute pulmonary embolism. The New England journal of medicine, Vol.358, No.10, (March 2008), pp. 1037-52, ISSN 0028-4793

ten Wolde, M., Söhne, M., Quak, E., Mac Gillavry, M.R. \& Büller, H.R. (2004). Prognostic value of echocardiographically assessed right ventricular dysfunction in patients with pulmonary embolism. Archives of internal medicine, Vol.164, No.15, (August 2004), pp. 1685-9, ISSN 0003-9926

The PIOPED Investigators. (1990). Value of the ventilation/perfusion scan in acute pulmonary embolism. Results of the prospective investigation of pulmonary embolism diagnosis (PIOPED). JAMA: the journal of the American Medical Association, Vol.263, No.20, (May 1990), pp. 2753-9, ISSN 0098-7484

Torbicki, A., van Beek, E.J.R., Charbonnier, B., Meyer, G., Morpurgo, M., Palla, A. \& Perrier, A. (2000). Guidelines on diagnosis and management of acute pulmonary embolism. Task Force on Pulmonary Embolism, European Society of Cardiology. European heart journal, Vol.21, No.16, (August 2000), pp. 1301-36, ISSN 0195-668X

Torbicki, A., Galié, N., Covezzoli, A., Rossi, E., De Rosa, M. \& Goldhaber, S.Z. (2003). Right heart thrombi in pulmonary embolism: results from the International Cooperative Pulmonary Embolism Registry. Journal of the American College of Cardiology, Vol.41, No.12, (June 2003), pp. 2245-51, ISSN 0735-1097

Torbicki, A., Perrier, A., Konstantinides, S., Agnelli, G., Galiè, N., Pruszczyk, P., Bengel, F., Brady, A.J.B., Ferreira, D., Janssens, U., Klepetko, W., Mayer, E., Remy-Jardin, M. \& Bassand, J.-P. (2008). Guidelines on the diagnosis and management of acute pulmonary embolism: the Task Force for the Diagnosis and Management of Acute Pulmonary Embolism of the European Society of Cardiology (ESC). European heart journal, Vol.29, No.18, (September 2008), pp. 2276-315, ISSN 0735-1097

Tsuji, K., Aoki, T., Tejima, E., Arai, K., Lee, S.-R., Atochin, D.N., Huang, P.L., Wang, X., Montaner, J. \& Lo, E.H. (2005). Tissue plasminogen activator promotes matrix 
metalloproteinase-9 upregulation after focal cerebral ischemia. Stroke; a journal of cerebral circulation, Vol.36, No.9, (September 2005), pp. 1954-9, ISSN 0039-2499

Uflacker, R. (2001). Interventional therapy for pulmonary embolism. Journal of vascular and interventional radiology: JVIR, Vol.12, No.2, (February 2001), pp. 147-64, ISSN 10510443

Uzuelli, J.A., Dias-Junior, C.A.C. \& Tanus-Santos, J.E. (2008). Severity dependent increases in circulating cardiac troponin I and MMP-9 concentrations after experimental acute pulmonary thromboembolism. Clinica chimica acta; international journal of clinical chemistry, Vol.388, No.1-2, (February 2008), pp. 184-8, ISSN 0009-8981

van Belle, A., Büller, H.R., Huisman, M.V., Huisman, P.M., Kaasjager, K., Kamphuisen, P.W., Kramer, M.H.H., Kruip, M.J.H.A., Kwakkel-van Erp, J.M., Leebeek, F.W.G., Nijkeuter, M., Prins, M.H., Sohne, M. \& Tick, L.W. (2006). Effectiveness of managing suspected pulmonary embolism using an algorithm combining clinical probability, D-dimer testing, and computed tomography. JAMA: the journal of the American Medical Association, Vol.295, No.2, (January 2006), pp. 172-9, ISSN 1538-3598

Van den Steen, P.E., Dubois, B., Nelissen, I., Rudd, P.M., Dwek, R.A. \& Opdenakker, G. (2002). Biochemistry and molecular biology of gelatinase B or matrix metalloproteinase-9 (MMP-9). Critical reviews in biochemistry and molecular biology, Vol.37, No.6, (December 2002), pp. 375-536, ISSN 1040-9238

Walther, A., Schellhaass, A., Böttiger, B.W. \& Konstantinides, S. (2009). [Diagnosis, therapy and secondary prophylaxis of acute pulmonary embolism. Presentation of and commentary on the new ESC 2008 guidelines]. Der Anaesthesist, Vol.58, No.10, (October 2009), pp. 1048-54, ISSN 0003-2417

Wan, S., Quinlan, D.J., Agnelli, G. \& Eikelboom, J.W. (2004). Thrombolysis compared with heparin for the initial treatment of pulmonary embolism: a meta-analysis of the randomized controlled trials. Circulation, Vol.110, No.6, (August 2004), pp. 744-9, ISSN 0009-7322

Wang, X., Tsuji, K., Lee, S.-R., Ning, M., Furie, K.L., Buchan, A.M. \& Lo, E.H. (2004). Mechanisms of hemorrhagic transformation after tissue plasminogen activator reperfusion therapy for ischemic stroke. Stroke; a journal of cerebral circulation, Vol.35, No.11 Suppl 1, (November 2004), pp. 2726-30, ISSN 0039-2499

Wells, P.S., Anderson, D.R., Rodger, M., Stiell, I., Dreyer, J.F., Barnes, D., Forgie, M., Kovacs, G., Ward, J. \& Kovacs, M.J. (2001). Excluding pulmonary embolism at the bedside without diagnostic imaging: management of patients with suspected pulmonary embolism presenting to the emergency department by using a simple clinical model and d-dimer. Annals of internal medicine, Vol.135, No.2, (July 2001), pp. 98107, ISSN 0003-4819

Wood, K.E. (2002). Major pulmonary embolism: review of a pathophysiologic approach to the golden hour of hemodynamically significant pulmonary embolism. Chest, Vol.121, No.3, (March 2002), pp. 877-905, ISSN 0012-3692

Worth, H. (2009). Aktuelles Management der akuten Lungenembolie. Der Pneumologe, Vol.6, No.6, (November 2009), pp. 378-389, ISSN 1613-5636 


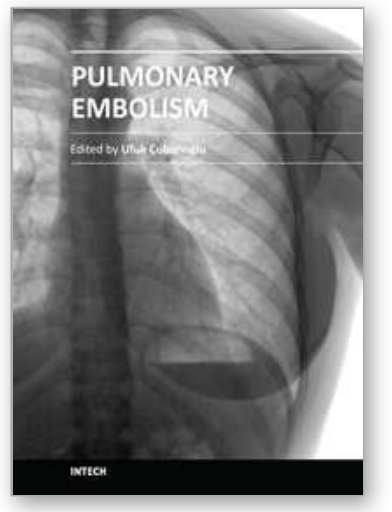

\author{
Pulmonary Embolism \\ Edited by Dr. Ufuk Çobanoğlu
}

ISBN 978-953-51-0233-5

Hard cover, 236 pages

Publisher InTech

Published online 14, March, 2012

Published in print edition March, 2012

Pulmonary embolism is a serious, potentially life-threatening cardiopulmonary disease that occurs due to partial or total obstruction of the pulmonary arterial bed. Recently, new improvement occurred in the diagnosis and treatment of the disease. The aim of this disease is to re-review pulmonary embolism in the light of new developments. In this book, in addition to risk factors causing pulmonary embolus, a guide for systematic approaches to lead the risk stratification for decision making is also presented. In order to provide a maximum length of active life and continuation of functional abilities as the aim of new interventional gerontology, the risk factors causing pulmonary embolus in elderly individuals are evaluated, and the approach to prevention and treatment are defined. The risk of the development of deep vein thrombosis and pulmonary embolism, combined with obesity due to immobility, the disease of this era, irregular and excessive eating, and treatment management are highlighted. Non-thrombotic pulmonary emboli are also covered and an attempt is made to constitute an awareness of this picture that can change the treatment and prognosis of the disease to a considerable extent. In addition to the pathophysiological definition of pulmonary embolus, the priority goal of quick and definitive diagnosis is emphasized, and diagnostic strategies are discussed in the book. A numerical analysis of the vena cava filters, which is a current approach to prevent pulmonary emboli recurrences, is presented in the last chapter.

\title{
How to reference
}

In order to correctly reference this scholarly work, feel free to copy and paste the following:

Diana Mühl, Gábor Woth, Tamás Kiss, Subhamay Ghosh and Jose E. Tanus-Santos (2012). Pathophysiology, Diagnosis and Treatment of Pulmonary Embolism Focusing on Thrombolysis - New approaches, Pulmonary Embolism, Dr. Ufuk Çobanoğlu (Ed.), ISBN: 978-953-51-0233-5, InTech, Available from: http://www.intechopen.com/books/pulmonary-embolism/pathophysiology-diagnosis-and-treatment-ofpulmonary-embolism-focusing-on-thrombolysis-new-approache

\section{INTECH}

open science | open minds

\section{InTech Europe}

University Campus STeP Ri

Slavka Krautzeka 83/A

51000 Rijeka, Croatia

Phone: +385 (51) 770447

\section{InTech China}

Unit 405, Office Block, Hotel Equatorial Shanghai

No.65, Yan An Road (West), Shanghai, 200040, China

中国上海市延安西路65号上海国际贵都大饭店办公楼405单元

Phone: +86-21-62489820 
Fax: +385 (51) 686166

Fax: +86-21-62489821

www.intechopen.com 
(C) 2012 The Author(s). Licensee IntechOpen. This is an open access article distributed under the terms of the Creative Commons Attribution 3.0 License, which permits unrestricted use, distribution, and reproduction in any medium, provided the original work is properly cited. 